\title{
The Finnish Battle for Identity: Finnish Socialism, Nationalism And Russian Ideological Intervention in the Finnish Civil War
}

\author{
Alexander Maavara
}

Shortly before he returned to Russia in 1917, Vladimir Lenin expressed his support for Finland, or, as he referred to it: "one of the most advanced republican countries," to receive independence from the Russian Empire. ${ }^{1}$ Lenin hoped that an independent Finland, which had "developed democracy relatively peacefully and won over a majority of the people to socialism," 2 would come to support the Russian proletariat in the global revolution. Lenin's prediction proved incorrect as Finland erupted into a civil war shortly after gaining its independence in December 1917. The civil war was fought between the Finnish Whites and Reds, ending with over 30,000 dead and the defeat of the Reds, despite the pre-war popularity and support of socialism. Lenin had falsely assumed that Finland's developed socialism corresponded with an equally developed militant revolutionary culture that would allow the Finnish socialists to easily seize power. This assumption led to the Finnish Reds becoming heavily dependent on Russian revolutionary ideology and material support. This dependence would allow the Finnish Whites to mobilize Finnish nationalism and frame the conflict as a War of Liberation against Russification, leaving a hostile nation on the Soviet Union's border.

Lenin's misstep was grounded in a misinterpretation of how Finland's position in the Russian Empire led to the evolution of a different socialist culture than existed in Russia itself. The Grand Duchy of Finland held privileged autonomy, maintaining its own legislature (the Diet) and executive (the Senate), while foreign relations were controlled by Russia. The right to

\footnotetext{
${ }^{1}$ C. Jay Smith, Finland and the Russian Revolution 1917-1922 (University of Georgia Press, 1958), 15.

2 Ibid.
} 
political assembly meant that socialism in Finland developed along Western Marxist ideological lines more similar to the situation in Germany than in Russia. ${ }^{3}$ Unlike the Russian socialist parties prior to the 1905 Revolution, the dominant Social Democratic Party (SDP) organized publically in parliament and in trade unions. Its parliamentary origins meant the SDP did not develop a revolutionary tradition like the Russian socialists. While the SDP believed in the Marxist concept of social revolution as the driving force of history, the mainstream SDP believed that revolution was a spontaneous event and did not have to be forced by clandestine revolutionary groups. Finnish socialism developed as an inherently nationalistic organization. Finnish nationalists throughout the $20^{\text {th }}$ Century did not want complete separation from Russia but Finns fiercely guarded their autonomous status within the Empire. In fact, most felt Finland benefited from its relationship with Russia. In this sense, Finnish socialism placed greater emphasis on self-determination than on internationalism, which accounted for their lack of cooperation with Russian socialist movements.

The Finnish socialists' role in the 1905 Revolution exemplified their parliamentary procedure aimed at protecting Finnish autonomy along with their disinterest with Russian socialism. In comparison to Russia, which was revolting for political rights it never had, Finland participated to stop Russification policies and recover lost constitutional rights. The Russification of Finland had begun in February 1899 when Tsar Nicholas II released a manifesto mandating Russian be the language of the Finnish civil service, and it peaked in 1903 when the Governor General was granted dictatorial powers. ${ }^{4}$ As Russians rose in rebellion after Bloody Sunday, Finland protested in a manner befitting its political freedoms. Socialists and non-socialists adopted a policy of "passive resistance," which culminated in a five-day general strike and

\footnotetext{
${ }^{3}$ John H. Hodgson, Communism in Finland: A History and Interpretation (Princeton University Press, 1967), 3.

${ }^{4}$ Ibid., 4-5.
} 
convinced the Tsar to withdraw his Russification policies. ${ }^{5}$ The only socialist revolutionary group in Finland in 1905 was the short-lived Finnish Red Guard, which formed independently from the SDP. ${ }^{6}$

After 1905, communications between the Finnish SDP and the Russian Social Democratic Labour Party (RSDLP) were established and a conference held in 1906. The proceedings reveal that the SDP were not aware of the split within the RSDLP and that they were actually dealing with the Bolsheviks, with whom they held little ideological relation. ${ }^{7}$ The SDP continued relations with the Bolsheviks, despite the SDP's closer ideological ties to the Mensheviks, because the Bolsheviks were more strongly supportive of Finnish autonomy. The conference established that any support between the Finnish and Russians would be limited to Finns providing havens for Russian fugitives and small donations to all Russian socialist parties. In return, the Finns made it clear they did not want direct support from the Russians, stating in the minutes that: "the class struggle should not spread across the frontiers..." lest it threaten Finland's autonomy. ${ }^{8}$

Before 1917, Finnish socialism had little revolutionary experience and was unprepared for the Russian Revolution's impact. It would result in the fracture of the Finnish socialist movement in 1917. The pre-revolutionary SDP leadership was reluctant to abandon their parliamentary tactics and ideology, which resulted in their failure to prevent the Civil War. Meanwhile, the resurgent Red Guard would grow rapidly, co-opting Bolshevik revolutionary rhetoric to promote class warfare. This rapid importation of Russian revolutionary ideology and

\footnotetext{
${ }^{5}$ D. G. Kirby, Finland in the Twentieth Century: A History and an Interpretation (University Of Minnesota Press, 1980), $28-31$.

${ }^{6}$ Anthony F. Upton, Finnish Revolution 1917-18 (Minneapolis: University of Minnesota Press, 1981 ), 9.

${ }^{7}$ David Kirby, "The Finnish Social Democratic Party and the Bolsheviks," Journal of Contemporary History 11, no. 2 (January 1, 1976): 182.

${ }^{8}$ Yrjõ Sirola, "The Finnish Social Democratic Party and the Russian Revolutionary Movement: Extracts from the Minutes of the Party Conference," in Finland and Russia 1808 - 1902: From Autonomy to Independence - A Selection of Documents, trans. D. G. Kirby (London: The MacMillan Press LTD, 1975), 117.
} 
the Red Guard's ties with occupying Russian soldiers would be framed as Russification by the Finnish Whites, who turned the conflict into a war of liberation.

Finland resembled a neutral state in the First World War despite its subservience to Russia. Finns were exempt from Russian conscription laws and the war did not approach Finnish borders until 1917. However, throughout the war, the Finnish would begin to see themselves as an occupied state and suspected that the Tsar was using the war as an excuse to reignite Russification. The Russian Government, fearing an invasion aimed at Petrograd through Finland, increased the Russian military presence until approximately 125,000 Russian soldiers were stationed in Finland. ${ }^{9}$ Furthermore, fifty non-socialist nationalists were also exiled to Siberia, including future Finnish White political leader P. E. Svinhufvud. ${ }^{10}$ The non-socialist nationalists were targeted because unlike the SDP, they had developed into a political revolutionary organization in 1904, called the Finnish Active Resistance Party. The Activists were the first Finnish party to promote clandestine revolutionary groups, armed militias, propaganda production, and support of Russian revolutionaries, not in ideological comradery but in the spirit of opportunism. ${ }^{11}$ Many began to see a Russian defeat as the only hope for Finnish freedom, such as the 2,000 Finns who absconded to Germany to form the $27^{\text {th }}$ Royal Prussian Jäger Battalion. ${ }^{12}$ The Jägers were a nationalist force which later joined the White Army, although they opposed Russification, not socialism. The SDP chose not to support the Jäger movement as it did not

\footnotetext{
${ }^{9}$ Irina Novikova, "The Provisional Government and Finland: Russian Democracy and Finnish Nationalism in Search for Peaceful Coexistence," in Russian Empire: Space, People, Power, 1700 - 1930, ed. Jane Burbank, Mark von Hagen, and Anatolyi Remnev (Bloomington: Indiana University Press, 2007), 414.

${ }^{10}$ Smith, Finland and the Russian Revolution 1917-1922, 8.

${ }^{11}$ D. G. Kirby, trans., "The Programme of the Finnish Active Resistance Party, Adopted at the Extraordinary Party Conference, 5 January 1907," in Finland and Russia 1808 - 1902: From Autonomy to Independence - A Selection of Documents (London: The MacMillan Press LTD, 1975), 121 - 122.

12 J. Hampden Jackson, "German Intervention in Finland, 1918," The Slavonic and East European Review 18, no. 52 (1939): 93.
} 
align with their parliamentary tactics but they did not forbid socialists to join, which many did. ${ }^{13}$ Furthermore, the White Army would be led by Finnish-born Carl Gustaf Emil Mannerheim, who was a former Russian Imperial general, and enemy of the Jägers. The Jägers joined the Whites despite Mannerheim's leadership because by the time they returned to Finland, the Red Guards had become synonymous with Russian troops.

General Mannerheim stated ardently in his memoirs that the main cause of the Civil War "was Finland's proximity to Petersburg, the hearth of the revolution, and the fact that there were in the country numerous Russian garrisons, all infected by it." ${ }^{14}$ This analysis, albeit written in 1950, is not far from the truth, since it was Russian troops that contributed revolutionary rhetoric and caused anarchy in Finnish streets during the Revolution of 1917. Even before the revolution Finns of all political affiliations had long deplored the presence of Russian soldiers, especially with regard to their relationships with Finnish women, which worsened as discipline broke down among the Russian garrisons in Finland as a result of the revolution. The Finnish press began running daily reports on sexual assaults perpetrated by Russian soldiers. ${ }^{15}$ The revolution led to a complete collapse of discipline among the Russian garrisons in Finland, and the dissolution the Tsarist police force. The first protective corps units were formed by the Finnish Whites for the purpose of expelling Russian troops from Finland, but the Russians did not recognize the legitimacy of the protective corps, resulting in violent clashes between the two forces. ${ }^{16}$ The violence between White units and Russians became so widespread that Russian sailors temporarily kidnapped Svinhufvud shortly after he became the head of government and

\footnotetext{
${ }^{13}$ Hodgson, Communism in Finland, 21.

${ }^{14}$ Carl Gustaf Emil Mannerheim, The Memoirs of Marshal Mannerheim, trans. Eric Lewenhaupt (London: Cassell and Company Ltd, 1953), 130.

${ }^{15}$ Upton, Finnish Revolution 1917-18, 16, 48 - 49.

${ }^{16}$ Pekka Kalevi Hamalainen, In Time of Storm: Revolution, Civil War, and the Ethnolinguistic Issue in Finland (Albany: State University of New York Press, 1984), 13.
} 
threatened the bombardment of Helsinki if the White Guard did not disarm. ${ }^{17}$ Svinhufvud became more committed to the White Guards, and two days later legitimized them as the official army of Finland. The formation of the White Guards was not an altruistic move made by the non-socialists, who had their own political motives, but the chaos triggered by the Russians provided a necessary motive to mobilize forces to cement their own power.

The Russian garrisons were not only contributing to the rising anti-Russian sentiment in Finland and causing disorder, they were also actively educating the Finnish population in Russian revolutionary ideology. The garrison-formed Soviets quickly became loyal to the Bolshevik party. The main Bolshevik organizations were the Northern Oblast Congress of Soviets and the Baltic Fleet organization known as the Tsentrobalt. ${ }^{18}$ These Soviets became some of the most radical Bolsheviks in all of the former Russian Empire. ${ }^{19}$ These Russian soldiers began spreading radical ideas which had never before been prominent in Finnish socialism, such as the dictatorship of the proletariat and internationalism. Russian troops had significant contact with the 40,000 laborers that had been employed constructing fortifications during the war and, as they were left unemployed by the revolution, many joined the Red Guard. ${ }^{20}$ Colonel M. S. Svechnikov, a Bolshevik officer in Finland, describes the impact of Russian troops: "... throughout their stay in Finland representatives of the Russian army had always emphasized in assemblies, meetings, manifestoes, etc., their solidarity with the Finnish workers and had promised to support them when the critical moment should come." ${ }^{21}$ The Bolshevik presence convinced Lenin during his exile in Finland in August 1917, of Finland's ripeness for revolution,

\footnotetext{
${ }^{17}$ Upton, Finnish Revolution 1917-18, 255.

${ }^{18}$ Smith, Finland and the Russian Revolution 1917-1922, 13.

${ }^{19}$ Novikova, "The Provisional Government and Finland," 413.

${ }^{20}$ Upton, Finnish Revolution 1917-18, 17 - 18; Henning Sõderhjelm, The Red Insurrection in Finland in 1918: A Study Based on Documentary Evidence (Westport, Conn: Hyperion Press, 1919), 14.

${ }^{21}$ Hodgson, Communism in Finland, 73.
} 
and made him abandon his earlier reservation that "without coal and iron, the Finns could not accomplish a socialist revolution alone." ${ }^{22}$ Lenin's observation was flawed, however. He assumed that the Bolshevism of the Red Guard and Russian soldiers represented revolutionary enthusiasm across the entire socialist movement. He did not realize that the importation of revolutionary culture was being compared to Russification among conservative and moderate socialist elements.

As the Russian soldiers indoctrinated Finnish workers with revolutionary rhetoric, the SDP leadership was attempting to maintain their parliamentary mandate but were failing to do so. Despite the suspension of the Diet, elections were still held and the SDP held a majority at the beginning of the Revolution. Parliamentary debate began when the Russian Provisional Government released a manifesto on March 20, 1917, promising internal autonomy of Finland in the future Russian state. At this point, the Finnish non-socialist nationalists approached the SDP, offering to form a coalition government in order to achieve the maximum level of independence diplomatically from Russia. ${ }^{23}$ The SDP refused due to ideological dogmatism forbidding an alliance with the bourgeoisie, which was partly fuelled by an internal debate that Finland first needed to go through its own bourgeoisie revolution to overthrow the remnants of feudalism in Finland, an event that the SDP intended to wait for. ${ }^{24}$ The SDP's refusal to negotiate resulted in the Russian Provisional Government dissolving the Finnish Diet and ordering new elections that were won by the non-socialist parties. ${ }^{25}$ At this point the SDP began to recognize the radicalism of the Red Guards. This was the case in Turku when the moderate SDP tried and failed to purge

\footnotetext{
${ }^{22}$ Norman E. Saul, “Lenin's Decision to Seize Power: The Influence of Events in Finland,” Soviet Studies 24, no. 4 (April 1973): 497.

${ }^{23}$ Upton, Finnish Revolution 1917-18, 29 - 30.

${ }^{24}$ Ibid., 7.

${ }^{25}$ Novikova, "The Provisional Government and Finland," 416.
} 
radical Red Guards who were boasting to undertake revolution themselves. ${ }^{26}$ The SDP convened an Extraordinary Congress on November $25^{\text {th }} 1917$ to deliberate tactics moving forward. ${ }^{27}$ The SDP were then split into two main groups - a parliamentary group and a revolutionary group. The parliamentary group advocated for a de-escalation of violence and the formation of a coalition with the non-socialists, whereas the revolutionary group advocated a seizure of power with Russian support.

Joseph Stalin appeared before this Congress to encourage the Red Guard to rise up against the Finnish government and the SDP leadership, which he claimed attempted to disperse the Red Guard. ${ }^{28}$ The SDP decided to continue its parliamentarian tradition, but the Red Guard did not accept this decision and moved ahead with revolution, illustrating their lack of accountability to the SDP leadership. The Red Guards themselves recognized that they would be breaking their own ideological policy and the will of the party if they were to "follow the Russian tactic and make a social revolution." ${ }^{29}$ In their power struggle with the SDP leadership, the Red Guard's influence proved decisive. On 23 January 1918, Lenin and the Red Guard set the Finnish Revolution in motion without consulting the SDP; Lenin had promised a trainload of arms from Petrograd and ordered the seizure of rail depots along southern Finland. When the SDP were informed that the Finnish socialists had crossed this boundary, they were paralysed with fear that the Russians would abandon them. ${ }^{30}$ Some Finnish socialists did their best to highlight the difference between the Tsarist and the Bolsheviks but these efforts failed. ${ }^{31}$ Finnish socialism had ceased to be Finnish, and neither the SDP nor the Red Guard recognized that by

\footnotetext{
${ }^{26}$ Hamalainen, In Time of Storm, $50-51$.

${ }^{27}$ Hodgson, Communism in Finland, 46 - 47.

${ }^{28}$ Smith, Finland and the Russian Revolution 1917-1922, 29.

${ }^{29}$ D. G. Kirby, trans., "The Red Guards Demand Revolution - Minutes of the Meeting of the General Staff of the Red Guards, 11 January 1918," in Finland and Russia 1808 - 1902: From Autonomy to Independence - A Selection of Documents (London: The MacMillan Press LTD, 1975), 220.

${ }^{30}$ Upton, Finnish Revolution 1917-18, $254-255$.

${ }^{31}$ Hamalainen, In Time of Storm, $14-15$.
} 
allying with the Bolsheviks, they were inserting their cause directly into the Russification narrative that the nationalists were concocting.

The White Finn perception of the events leading up to the Civil War clearly shows how they had begun to see the Red Guard as a Russian entity. This was mostly due to the fact that the Red Guard did not attempt to hide their Russian support. Even before battle lines were drawn, elements of the Red Guard boasted to the Finnish Senate that Russians would fight alongside their Finnish comrades and that weapons were already being supplied from Petrograd. ${ }^{32}$ It was very clear in the days leading up to the Red Coup that the socialists were about to vie for power and two key documents outline the White perception of events at the beginning of the Civil War. The first of those documents is three declarations that were released to the Finnish people, the Russian government, and every great power on the $25^{\text {th }}$ and $26^{\text {th }}$ of January $1918 .^{33}$ The declarations stated that the Russians were violating the sovereignty of Finland and that their influence was pushing the country to civil war. The second document is the final act of the White Senate, dated January $28^{\text {th }} 1918$ (just before the Reds took Helsinki) declaring war against "...some Finnish citizens, supported by foreign bayonets..." ${ }^{34}$ Both of these statements make it clear that the White leadership felt that the root cause of this revolt was ideological interference from Russia. Acting on his own volition and almost simultaneously with the Red Coup in Helsinki, Mannerheim moved to disarm Russian garrisons in north Finland. Mannerheim noted that since his first operations were against occupying Russians, whom the Red Guards rushed to aid, that the coming conflict was a War of Liberation. ${ }^{35}$

\footnotetext{
${ }^{32}$ Smith, Finland and the Russian Revolution 1917-1922, 25.

${ }^{33}$ Sõderhjelm, The Red Insurrection in Finland in 1918, 75 - 77.

${ }^{34}$ Smith, Finland and the Russian Revolution 1917-1922, 37.

${ }^{35}$ Mannerheim, The Memoirs of Marshal Mannerheim, 141.
} 
The Red Guards were almost immediately disappointed by their Russian allies. Just two days after the beginning of Civil War on January $30^{\text {th }}$, the Chief of the Red Guard's general staff reported that Russian troops were not living up to promises made prior to the revolution. ${ }^{36}$ Despite the Chairman of Tsentrobalt pledging to send "all our troop units into the fight with the white bands," many Russian troops refused to fight. ${ }^{37}$ The Russian troops may have wanted to support the Finnish Revolution, but when it came to fighting a motivated and well-led enemy, most Russians chose to renege on their promises. The situation completely collapsed on March 3, 1918, when the Treaty of Brest-Litovsk was signed between Germany and the Bolsheviks, mandating the withdrawal of all Russian troops from Finland. ${ }^{38}$ The Red Guard had bet everything on the Russians supporting them but the Russians fell short of their promise, resulting in the Red Guard receiving the brunt of Finnish Russophobia, but none of the Russian military might.

Despite being abandoned by the Russians, the Finnish Red Guard continued to publically seek Russian aid, which only further cemented support for the White nationalistic cause. The Red Finn-Soviet Treaty signed on March $1^{\text {st }} 1918$ proved to be some of the best propaganda the Whites could hope for. Articles I to XII outlined the terms of Finnish independence but Articles XIII and XIV almost immediately robbed Finland of sovereignty by granting Russian citizens the same rights in Finland given to Finnish citizens and vice versa. ${ }^{39}$ The issue of dual citizenship had been one of the most contentious issues during the 1899-1905 Russification periods and by granting it to the Bolsheviks, Red Finland appeared as though it were a Russian puppet.

\footnotetext{
${ }^{36}$ Hodgson, Communism in Finland, 72 - 73.

${ }^{37}$ Ivar Smilga, "The Finnish Revolution and the Russian Troops," in Finland and Russia 1808 - 1902: From Autonomy to Independence - A Selection of Documents, trans. D. G. Kirby, 1975th ed. (London: The MacMillan Press LTD, n.d.), 232.

${ }^{38}$ Smith, Finland and the Russian Revolution 1917-1922, 45.

${ }^{39}$ Ibid., $57-58$.
} 
Furthermore, other Red Finnish edicts proved worrisome. Paragraph 15 of the Red Finnish Constitution referenced ensuring rights to a linguistic minority, but the ambiguity led many Finns to think it was not Swedish people that were to be the minority but rather the Russians. ${ }^{40}$ This was just one of the actions that led to the alienation of Swedish speaking Finns, who represented approximately $11 \%$ of the population during the 1910 s. $^{41}$ As early as March 1917, Finnish socialists promoting revolution against the Swedish aristocracy went so far as to label the entire Swedish speaking population of Finland as the class enemy. ${ }^{42}$ Swedish-speaking Finns, including industrial workers with socialist ties, chose to remain neutral or join the Whites in response to this rhetoric. ${ }^{43}$

The Finnish Whites framing of Bolshevism as a new form of Russification implied an idea that many of the Finnish conservatives would later regret: the continuation of Finnish socialism. All of the aforementioned White propaganda focused specifically on Russian occupation, Russification, and a radical minority within Finland but it never inherently opposed Finnish socialism. Given the fractured state of the SDP leadership at the beginning of the Civil War, several leaders, namely Väinö Tanner, stayed neutral during the War. Upon a White victory, these socialists offered to placate the working class with a combination of their pre-War parliamentary tactics and Finnish nationalism. They released a statement on April $16^{\text {th }} 1918$ entitled Proclamation "To the Workers of Finland" which declared that the Red insurrection was the work of a small, radical group which, by '...relying on Russian help, have irresponsibly led the social-democratic working-class movement in our country astray., ${ }^{44}$ The SDP returned to

\footnotetext{
${ }^{40}$ Hamalainen, In Time of Storm, 60.

${ }^{41}$ Pekka Kalevi Hamalainen, The Nationality Struggle between the Finns and the Swedish-Speaking Minority in Finland, 1917-1939 (Ann Arbor, Mich.: Indiana University Press, 1966), 16.

${ }^{42}$ Hamalainen, In Time of Storm, 38.

43 Ibid., 46.

${ }^{44}$ Upton, Finnish Revolution 1917-18, 516.
} 
prominence in March 1919 when 80 Social Democrats took seats in Parliament. ${ }^{45}$ This continuation of Finnish socialism after the Civil War depicts how Bolshevism was unlikely to work in Finland, given that a significant portion of the SDP was committed to Finnish autonomy and parliamentary tactics.

The Finnish Civil War did not retain the moniker of War of Liberation for long. When the Russian participation and the atrocities committed by the Whites during the War became clear, revisionist historians and apologetic politicians refocused the conflict as an unfortunate class war caused by the economic troubles of the First World War. However, it is necessary to examine the perception of the Finnish as these events were occurring. The state of Finnish socialism and nationalism before 1917 meant it was resistant to foreign influences, particularly those from Russia, which is why the Finnish viewed the importation of Russian revolutionary ideology to be akin to Russification and the conflict to be a war of liberation against an aggressor. The introduction of Bolshevism by way of Russian soldiers made resistance an essential act of patriotism, but had Bolshevism been independently created in Finnish society it is possible the reception of it would have been very different.

\footnotetext{
45 David Kirby, "New Wine in Old Vessels? The Finnish Socialist Workers' Party, 1919-1923," The Slavonic and East European Review 66, no. 3 (1988): 428, 431.
} 


\section{Bibliography}

Hamalainen, Pekka Kalevi. In Time of Storm: Revolution, Civil War, and the Ethnolinguistic Issue in Finland. Albany: State University of New York Press, 1984.

Hamalainen, Pekka Kalevi. The Nationality Struggle between the Finns and the SwedishSpeaking Minority in Finland, 1917-1939. Ann Arbor, Mich.: Indiana University Press, 1966.

Hodgson, John H. Communism in Finland: A History and Interpretation. Princeton University Press, 1967.

Jackson, J. Hampden. “German Intervention in Finland, 1918." The Slavonic and East European Review 18, no. 52 (1939): 93-101.

Kirby, David. "New Wine in Old Vessels? The Finnish Socialist Workers' Party, 1919-1923." The Slavonic and East European Review 66, no. 3 (1988): 426-45.

Kirby, David. "The Finnish Social Democratic Party and the Bolsheviks.” Journal of Contemporary History 11, no. 2 (January 1, 1976): 99-113.

Kirby, D. G. Finland in the Twentieth Century: A History and an Interpretation. University Of Minnesota Press, 1980.

Kirby, D. G., trans. "The Programme of the Finnish Active Resistance Party, Adopted at the Extraordinary Party Conference, 5 January 1907.” In Finland and Russia 1808 - 1902: From Autonomy to Independence - A Selection of Documents. London: The MacMillan Press LTD, 1975.

Kirby, D. G., trans. "The Red Guards Demand Revolution - Minutes of the Meeting of the General Staff of the Red Guards, 11 January 1918.” In Finland and Russia 1808 - 1902: From Autonomy to Independence - A Selection of Documents. London: The MacMillan Press LTD, 1975.

Mannerheim, Carl Gustaf Emil. The Memoirs of Marshal Mannerheim. Translated by Eric Lewenhaupt. London: Cassell and Company Ltd, 1953.

Novikova, Irina. "The Provisional Government and Finland: Russian Democracy and Finnish Nationalism in Search for Peaceful Coexistence.” In Russian Empire: Space, People, Power, 1700 - 1930, edited by Jane Burbank, Mark von Hagen, and Anatolyi Remnev. Bloomington: Indiana University Press, 2007.

Saul, Norman E. "Lenin's Decision to Seize Power: The Influence of Events in Finland." Soviet Studies 24, no. 4 (April 1973): 491-505.

Sirola, Yrjõ. "The Finnish Social Democratic Party and the Russian Revolutionary Movement: Extracts from the Minutes of the Party Conference.” In Finland and Russia 1808 - 1902: 
From Autonomy to Independence - A Selection of Documents, translated by D. G. Kirby. London: The MacMillan Press LTD, 1975.

Smilga, Ivar. "The Finnish Revolution and the Russian Troops." In Finland and Russia 1808 1902: From Autonomy to Independence - A Selection of Documents, translated by D. G. Kirby, 1975th ed. London: The MacMillan Press LTD, n.d.

Smith, C. Jay. Finland and the Russian Revolution 1917-1922. University of Georgia Press, 1958.

Sõderhjelm, Henning. The Red Insurrection in Finland in 1918: A Study Based on Documentary Evidence. Westport, Conn: Hyperion Press, 1919.

Upton, Anthony F. Finnish Revolution 1917-18. Minneapolis: University of Minnesota Press, 1981. 